\title{
Childhood Central Nervous System Neoplasm
}

National Cancer Institute

\section{Source}

National Cancer Institute. Childhood Central Nervous System Neoplasm. NCI Thesaurus.

Code C5132.

A benign or malignant neoplasm of the brain, spinal cord, or meninges occurring in

children. Representative examples include posterior fossa astrocytoma, optic pathway glioma, medulloblastoma, ependymoma, and craniopharyngioma. 